\title{
The Fatimids: The Rise of a Muslim Empire
}

\author{
Shainool Jiwa \\ London, England: I.B. Tauris Publishers, 2018. 160 pages.
}

Shainool Jiwa's The Rise of a Muslim Empire is a two-volume historical work on the legacy of the Fatimid Empire. The first volume surveys the religious and sociopolitical underpinnings of Fatimid rule from its North African establishment in 909 to its transition to Egypt in 969. Jiwa's second volume focuses on the pinnacle of Fatimid society up until its decline from 969-1171. This review pertains to the first of the two volumes. Working within this phase, Jiwa details the reigns of the first four Imams: 'Abd Allāh al-Mahdī, Abū'l-Qāsim Muhammad, Ismāēil al-Manșūr, and al-Mưizz liDin Allāh. The second book, which is titled The Fatimid Rule from Egypt, discusses the latter ten Imams (4).

The first chapter covers the origins of the Fatimids in respect to both religious and geographical contexts. Jiwa starts by providing the historical background of Ismaili Shiism. Here, everything from the succession crisis of $632 \mathrm{CE}$ to the emergence of the different strands of Shiism are discussed. Jiwa describes the Ismaili sect as having held Ismā' ${ }^{\complement} \mathrm{l}$, the eldest son of Ja ${ }^{c}$ far al-Șādiq, to have been the chosen successor of his father, therefore making him Imam. Ismācil's ephemeral mortality caused for the Imamate to then pass over to his young son, Muhammad b. Ismā'ill, eponym of the sect (10). The Twelvers are described as having believed in the Imamate of Ja'far's youngest son, Mūsā, whose lineage gives root to the Imams of Twelver Shiism. Jiwa characterizes Ismaili beliefs as having rested on dawr al-satr (period of concealment) and $d a^{c} w a$ (religio-political mission) (11). The dawr al-satr refers to the Imams going into hiding with only their most trusted followers knowing their true identities. Subsequently, these followers promoted the recognition of these hidden Imams, which in large part refers to $d a^{c} w a$ (the act of inviting). Jiwa explains that during dawr al-satr (765-909 CE) Ismaili doctrine had spread as far as from Yemen to Ifriqiya (modern-day Tunisia and eastern Algeria) (12), with its most prominent adherents being the Kutama Berbers of North Africa.

Under the teachings of Abū 'Abd Allāh al-Shī'ī, a pronounced Ismaili $d \bar{a} \bar{\imath}$ (inviter), the Kutama had aspired to establish the dawlat al-haqq (the righteous state) (16). This aspiration materialized under the allegiance of 'Abd Allāh al-Mahdī who had been pronounced as Imam by his predeces- 
sor and later recognized as the mahdī (messianic figure) (20). This belief, nonetheless, was not accepted by all Ismailis, particularly those following Hamdān Qarmat, who later came to be known as the Qaramita (21). Salamiyya (a town located in Syria), the town where 'Abd Allāh al-Mahdī had resided, became unsafe due to Abbasid persecution, causing the Imam to migrate to various locations and eventually Sijilmasa (22). Meanwhile, the Kutama had grown to such a force that they had been able to seize control over Qayrawān of North Africa under the leadership of al-Shīì (22). When al-Mahdi was later arrested in Sijilmasa and the news spread to the Kutama, a campaign of soldiers marched to secure his release and bring him to Qayrawān. Having accomplished this, the Fatimid State came into fruition (22). Jiwa provides sources detailing the events which led up to the Fatimid establishment, including eyewitness accounts from Ja ${ }^{c}$ far al-Hājib’s Sìrat Ja far al-Hājib, secondary sources such as Ahmad b. Ibrāhīm al-Naysābūrīs Istitār al-Imām ('The Concealment of the Imam'), and other historical works such as the influential Iftitāh al-da'wa wa-ibtidā' al-dawla ('Commencement of the Mission and the Beginnings of the State') authored by Abū Ḥanīfa al-Nu'mān (29-30). These references help readers pinpoint who was instrumental in recording Fatimid history.

In chapter two, Jiwa discusses the establishment of the Fatimid state, giving details of its institutions, processes, and hallmark locations. Al-Mahdì is seen to have incorporated officials who had previously served the Aghlabids (the previous rulers of Qayrawān). In addition, institutions such as mazālim (oppressive acts) courts are discussed as having been established to provide redress for ordinary civilians against abuses of power (35). During this time of development, dissension amongst the Kutama is seen to have imploded on the basis of marginalized sentiments. Once having been one of the most loyal $d \bar{a} \bar{l}^{\top} \bar{s}$ to al-Mahdī, al-Shīi $\bar{i}$ had led a rebellion against his former Imam on charges of being a false mahdi. Ultimately this campaign was pacified, resulting in the execution of al Shī ${ }^{-}$. This chapter also reveals new characters who later became prominent figures in Fatimid history. The heir apparent or Prince Abū'l-Qāsim Muhammad, the eldest son of al-Mahdī, already took up much of his father's duties while his own son, Ismā'îl or al-Manșūr bi'llāh ('the One Who is Victorious by God') was entrusted by the sitting Imam, al-Mahdi (his grandfather), as his most faithful confidant (39). The port city of al-Mahdiyya which had been constructed by the Fatimids in 916 is described as having been unique in its architectural design and strategic in its location. Al-Mahdiyya served as the new Mediterranean capital and had secured the Fatimids a booming com- 
mercial fabric. Similarly, the city of Palermo in Sicily had been occupied by the Fatimids and had also brought a great deal of cultural exchange and goods. Jiwa brings out images of palaces and charts out maps of the port city to provide visual comprehension of the architecture.

Chapter three surveys the reign of al-Mansuūr, discussing his ascension to power under fraught circumstances and his construction of a new city. This chapter focuses attention on the reconstruction of Palermo in vivid archaeological detail. Readers are informed of the Khariji rebellion from Ifrīqiya spearheaded by Abū Yazīd al-Nukkarī. The Kharijis are described to have been insurmountable by the Fatimids, pushing their Empire as far back as to the Mediterranean coast of al-Mahdiyya (60). It was not until al-Hasan b. 'Alī al-Kalbī, the governor of Tunis, and his army pushed back against the Kharijis that the North African coastland would be recaptured (61). Despite this, the Kharijis were too difficult to overcome and remained at conflict with the Fatimids up until the death of Abü'l-Qāsim. Fearful that news of Abū'l-Qāsim's death would puncture the morale of the Fatimid war effort, al-Manșūr had managed to keep the news of his father's passing silent. After an eventful encounter, al-Manșūr would eventually go on to defeat Abū Yazìd's army and restore Fatimid rule. Following this victory, al-Manșūr began taking restorative measures to recover the now war-torn society. Socially considerate policies such as charity stipends, the appointment of a Sunni-based Maliki judge, and omission of taxes were all strides in this effort. But the most significant of his developments was the construction of a new capital called Mansuuriyya. Much of this city's structural inspiration came from the North African ancient ruins al-Manșūr had been enchanted by (68). Jiwa's training as a historian is evident in how she cites primary sources every chance she gets, from sermons to testimonies. Closing this chapter, Jiwa provides an anecdote recorded by al-Nu'mān which romantically relays the moment al-Manșūr knew that his son, al-Mu'izz li-Dīn Allāh, was ready to ascend to power (77). Jiwa's anecdotes connect the reader to the ethos of Fatimid personalities.

Chapter four delves into the reign of al-Manșūr's heir, al-Mu'izz (95375), who came into conflict with both the Umayyads and the Byzantines during his reign and would later live out his final days in his new capital, al-Qāhira al-Mu'izziya ('the Victorious City of al-Mu'izz')-modern-day Cairo (78). Beyond the royal family, Jiwa presents key stalwarts that the Empire was indebted to. Once servant to al-Mahdī, Jawhar, who was of Slavic origin, had risen through the ranks (serving both as scribe and commander in battle), eventually being entrusted with many honorable state positions. 
This chapter is the longest one of the book and attempts to accomplish many things. Along with discussing the battles which ensued during this juncture, Jiwa also fleshes out the theology of Ismaili beliefs. Al-Nu'mān is said to have written extensively on the topic-including his text written between 958 and 960, Da'ä'im al-Islām ('Pillars of Islam'), which delineates such fundamental concepts to Ismaili theology as walaya (allegiance and obedience), ìmān (faith), z̧āhir (exoteric), and bāțin (esoteric) (88-89). The early Fatimid age is described as having been a milieu of knowledge seeking, with debates and lectures taking place on a frequent basis. Through the majāis (teaching sessions) program, the Ismaili doctrine would proliferate to the broader society. Jiwa's text is filled with firsthand accounts which describe Fatimid institutions, ceremonies, and events, providing vivid pictures of what is being described (e.g., al-Nu'mān's description of the grand circumcision ceremony hosted in 962 and Ibn Haytham's description of the diversity of attendees and tailoring of lessons in the majalis by teachers such as Aflah b. Hārūn al-Mālūsī, 95). The tension between the Umayyads in Spain and the Fatimids is also presented in this chapter, depicted as stemming from their varying loyalties in the rivalry between 'Alì b. Abì Tâlib and Mu'āwiya. The coastal regions of the Mediterranean and North Africa would see many conflicts between the Fatimids and Umayyads; the Umayyads and the Byzantines worked together to suppress their Fatimid adversary, with the Byzantines launching campaigns on the parts of the Empire closest to Sicily while the Umayyads attacked the most western part. After briefly losing parts of their North African territories, the Fatimids eventually reasserted their control over the Maghrib, leaving the Umayyads no choice but to resort to a peace treaty (103). The Ismaili $d a^{c} w \bar{a}$ reached far and wide, with its message gaining adherents from the Gulf of Yemen to as far as Sind. Jiwa also describes the Kalbid dynasty of Fatimid Sicily, which had come under the governorship of al-Hasan al-Kalbī. During this period (960-65), Sicily had been the site of intense warfare between the Fatimids and the Byzantines, with two distinct battles resulting in the most pivotal outcomes for the region, namely the Pit and the Straits (119). Like the Umayyads, the Byzantines would also later come to negotiate terms of peace with the Fatimids in 958 (116).

Chapter five speaks to the venture the Fatimids made into Egypt in 966. Here, readers are presented with the terms acknowledged by local nobles such as Sharîf Abū Ja'far Muslim al-Husaynī and the Fatimids, the founding of the new capital (al-Qähira), and the relocation of al-Mu'izz along with a significant portion of the Manșūriyyan population in 972 . The 
chapter serves as both a close to the book and a cliffhanger for the second volume of the series (which turns to Fatimid rule in Egypt under the son of al-Mu'izz, Nizār b. al-Mu'izz). Capturing the cohesive religious fabric of Fatimid rule, Jiwa notes that al-Mucizz pledged to maintain Sunni religious life while ruling over Egypt (126); she describes pillars of Sunni Islam that can serve as points of contrast to the Ismaili tradition (127).

Individuals who can justly be seen as archetypes of the Fatimid intelligentsia are referenced both biographically and through their works. Jiwa introduces her readers to eminent characters including missionaries like Abū Ya ${ }^{c} q u ̄ b$ al-Sijistānī of Khurāsān (d. after 971); writers and thinkers who composed the Fatimid ideology such as Qādī al-Nu mān; poets who gave inspiration such as Muhammad b. Hānī; and generals who rendered their lives for the Fatimid Empire such as al-Hasan b. Ali al-Kalbī. Although some readers may be frustrated by the detail of jumping back and forth across names, dates, and events, those who are able to follow the work thematically will certainly find this work to be nothing short of informative. Jiwa impressively condenses a rich and fluid history into few pages while including the most essential elements, people, and institutions making up this period. Readers are provided with visual aids (maps, family tree charts, and city maps) to help identify and locations and structures which would otherwise come off as abstract and jargon-heavy. In addition, she includes colorful images of important monuments such as mosques, coins, and artifacts.

Ameen Omar

MA, Islamic Studies \& History The George Washington University 